\title{
Distribution of Landslides Triggered by the 1995 Hyogo-ken Nanbu Earthquake and Long Runout Mechanism of the Takarazuka Golf Course Landslide
}

\author{
Hiroshi Fukuoka, ${ }^{1, *}$ Kyoji Sassa, ${ }^{1}$ and Gabriele Scarascia-Mugnozza ${ }^{2}$ \\ ${ }^{1}$ Disaster Prevention Research Institute, Kyoto University, Uji 611, Japan \\ ${ }^{2}$ Earth Science Department, University of Rome "La Sapienza," 00185 Rome, Italy
}

\begin{abstract}
The 1995 Hyogo-ken Nanbu earthquake caused not only casualties and damage to buildings and civil structures but also many landslides. Most of the landslides were triggered or reactivated in the northeastern part of the Rokko Mountains, Nishinomiya and Takarazuka Cities, and the northern tip of Awaji Island. Based on the analysis of aerial photographs coupled with field surveys, 674 landslides were mapped within an area of about $700 \mathrm{~km}^{2}$. The observed landslides were mainly rock slides, rock falls, and rock/debris avalanches. Debris slides, complex slides, and slumps were also found. A few debris slides showed low apparent friction angle during motion with long runout distance. The investigations of landslide typology and distribution show that, based on the relationship between landslide frequency and distances from the assumed fault rupture zone, an attenuation trend can be observed which shows a significant decrease within $3 \mathrm{~km}$, while the maximum recorded distance was $10 \mathrm{~km}$. While focused on the long runout mechanism in the Takarazuka golf course landslide, an undrained loading ring shear test on saturated golf course soil was carried out and succeeded to reproduce the low apparent friction angle mobilized in the landslide.
\end{abstract}

\section{Introduction}

The earthquake $\left(M_{\mathrm{s}} 7.2, M_{\mathrm{w}} 6.9\right)$ which struck Kobe City and surrounding areas on 17 January 1995, 1 year after the Northridge, California earthquake, showed once again that further and stronger efforts are needed toward an effective mitigation of damage caused by natural disasters and risk reduction associated with geological hazard. The so-called Great Hanshin earthquake claimed 6,289 lives. Extensive damage to houses, buildings, transportation systems, and lifeline structures occurred. Peak horizontal accelerations as large as $0.8 \mathrm{~g}$ were recorded in the near-fault region from Kobe to Nishinomiya Cities (Irikura, 1995). The earthquake produced widespread ground failure, large-scale liquefaction and settlements in the artificial islands (Rokko and Port Island) in the range of 0.5 to $2 \mathrm{~m}$, and other liquefaction-induced phenomena on the mainland.

A large number of landslides occurred throughout the epicentral area, causing further casualties and damage as well as hampering rescue operations and relief efforts in urban areas around downtown Kobe. Among these, a few landslides including the Takarazuka golf course landslide showed a low apparent friction angle during motion with a long runout distance. In this paper, the regional distribution of landslides induced by this earthquake are described and some of the parameters which affected them are discussed. While focused on the long runout mechanism in the Takarazuka golf course landslide, an undrained loading ring shear test on saturated golf course soil was carried out to measure the apparent friction angle.

\section{Geological Setting}

The epicentral area can be divided into three areas from the Quaternary tectonic standpoint (Fujita et $a l .$, 1971). The first area is characterized by the prominent uplift of faulted big-scale blocks which form the Rokko Mountains and adjacent hilly lands. The Rokko Mountains are mainly composed of Late Cretaceous, highly faulted granitic rocks and

Received November 30, 1995; Accepted October 3, 1996

*To whom correspondence should be addressed. 

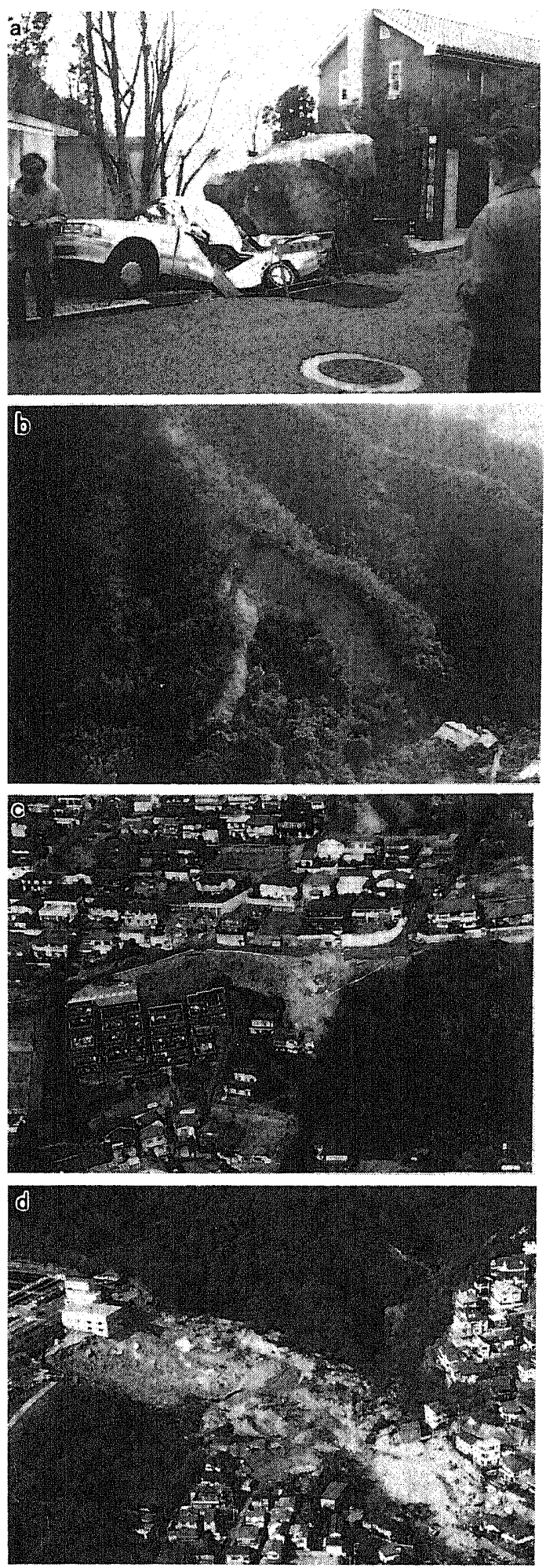

e
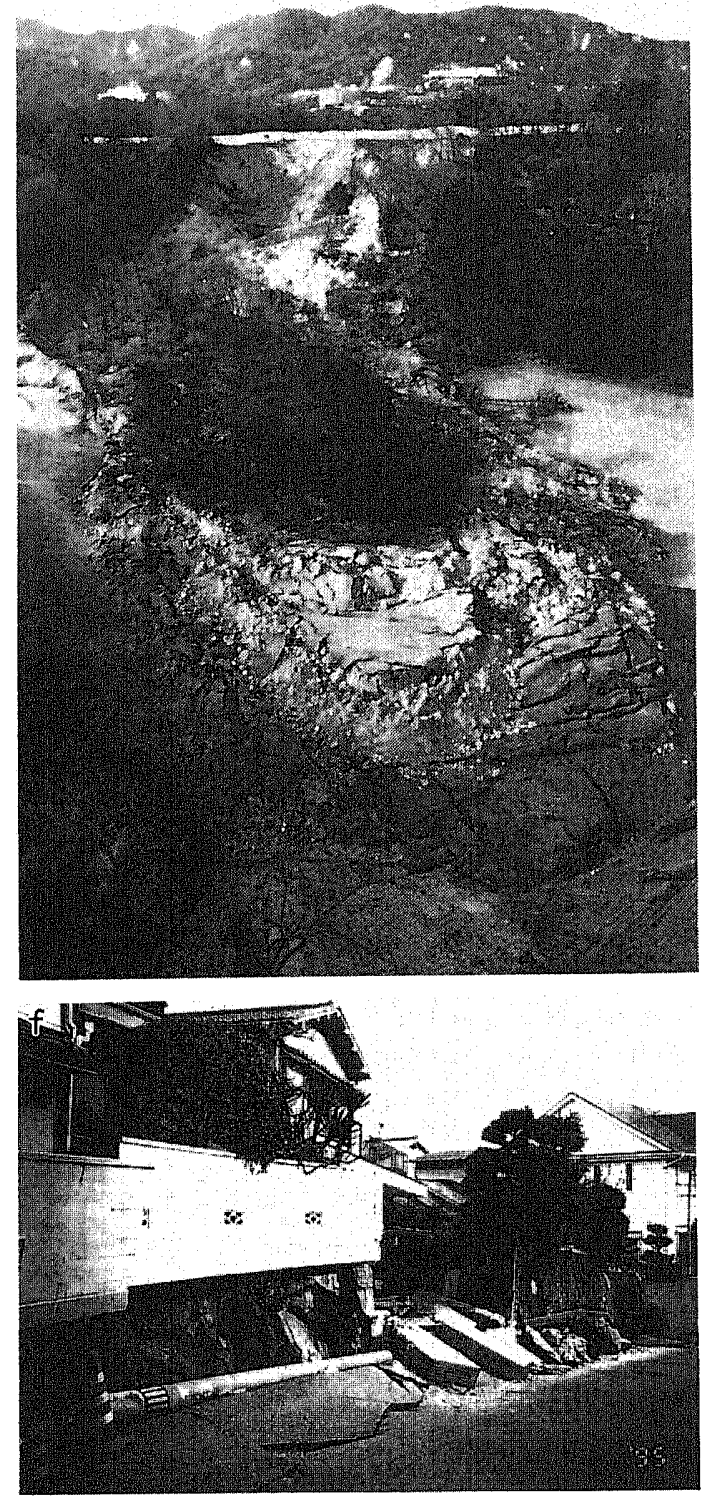

Fig. 1. Various landslides and rock falls triggered by the 1995 Hyogo-ken Nanbu earthquake: (a) Rock fall at Rokko Mountains (taken by K. Okunishi); (b) Oishi landslide which occurred on the Nojima fault (taken by K. Okunishi); (c) Nishiokamoto landslide, Higashinada-ku, Kobe; (d) Nikawa landslide, Nishinomiya City, which killed 34 people; (e) Takarazuka golf course landslide, Takarazuka City (taken by Sankei Shinbun Co. Ltd.); and (f) Horaku-cho landslide, Nishinomiya City (taken by T. Kamai).

J. Phys. Earth 
Miocene, weathered volcanic rocks. The surrounding hilly lands consist of Cenozoic clastic sequences ascribed to the Kobe Group formation (sandstones, mudstones, and tuffs) and are unconformably overlaid by Plio-Pleistocene Osaka Group formation (marine and lacustrine clay, sand, and gravel). The second area is represented by Awaji Island, which is composed of small-scale faulted blocks of granitic rocks formed by the same uplifting processes which led to the identification of the Rokkos on the mainland. Shallow deposits, which can be ascribed to both the Kobe and Osaka groups, overlay the granitic bedrock along the western and eastern shorelines of northernmost Awaji Island.

The third area, south and east of the Rokko Mountains, can be roughly divided into alluvial fans, flood plain, and reclaimed lands where a large part of the Kobe metropolitan area has been spreading in the last several decades; in particular, because of the expansion of many boroughs, mountain-foot areas have turned into densely populated residential sites. Further, the locations of the recorded aftershock epicenters fit the trend of the mapped active faults (RCEP/DPRI, 1995; Research Group for Active Faults of Japan, 1995).

\section{Landslide Typology and Distribution}

\subsection{Landslide typology}

The observed landslides were mainly rock slides, rock falls, and rock/debris avalanches; some debris slides, complex slides, and slumps were also found. Rockfalls involved boulders whose dimensions range from a few to $100 \mathrm{~m}^{3}$. Several boulders fell into a residential area west of Takarazuka City, damaging some cars (Fig. 1(a)) and at least two houses. Small to medium-scale (thousands of $\mathrm{m}^{3}$ ) rock-block slides and wedge failures along road cuts caused interruption along several sections of the Royu Toll Road in the Rokko Mountains, north of Ashiya City. Rock falls and rock slides were mapped also on Awaji Island, although their magnitudes were generally smaller than those on the mainland. Rock/debris avalanches, debris slides and complex slides also occurred. In the Rokko Mountains, many rock/debris avalanches originated in the upper part of existing debris flow tracks and most of the observed debris slides were shallow slides due to reactivation mechanisms, like the one observed on Awaji Island over the Nojima fault (Fig. 1(b)).

A number of shallow debris slides and soil slides occurred in urban areas northeast of Kobe. As an example, the shallow debris slide in Nishiokamoto (Fig. 1(c)) was caused by the failure of a roadfill along the Gosukebashi faultscarp. Subsequent investigation proved that the developed town behind the slide was landsliding. No other landslide occurred in the neighborhood but several tension cracks were observed along surrounding terraces and cliffs. These ground deformations are warning the possibility of a sudden failure under disturbing factors, such as heavy rainfall or further ground shaking.

One of the largest debris slides triggered by this earthquake traveled long, killing 34 people and causing heavy damage in Nikawa, Nishinomiya City (Fig. 1(d)). It can be regarded as a slide-flow slide caused by the sliding surface liquefaction (Sassa $e t$ al., 1996) of secondary deposits (e.g., embankment) of the Osaka Group located close to the facilities of a water purification plant. Some landslides were greatly influenced by the presence of saturated granular soils. Continuous seepage was observed on sand layers along the head-scarp of the slumpearthglide which occurred at the Takarazuka golf club (Fig. 1(e)). This landslide was located only $1 \mathrm{~km}$ north of the Nikawa landslide. The geology of the sliding surface materials of both landslides is Osaka Group, and there were very similar characteristics. This event represents an interesting case history of a long runout landslide enhanced by undrained loading into the saturated ground below the sliding mass. The detailed mechanism of the long runout of this landslide is discussed in Sec. 4 of this paper.

Figure 1(e) shows a Horaku-cho landslide in Nishinomiya City. This landslide moved slowly only a few meters, and was difficult to detect from the air survey. Most of these landslides took place in reclaimed urban hills at the foot of the Rokko Mountains and were detected by Kamai et al. (1995) through field survey.

\subsection{Distribution of landslides}

Low-altitude photographs (1:12,000 and 1:5,000 scale) of the epicentral area were taken on behalf of local governmental offices and national agencies within a few days of the mainshock event. The prompt analysis of the available stereopairs allowed the mapping of 631 landslides induced by the earthquake on a 1:10,000 scale map; the observed slope failures were then mapped on smaller scale maps $(1: 25,000$ and $1: 50,000)$ together with 43 slow 
landslides in an urban area detected by Kamai et al. (1995) as shown in Fig. 2. Soon after the mainshock, field surveys were carried out in order to check some uncertain situations, regarding both the recognition of actual earthquake-induced slope failures and their typology, because of the limited resolution and reliability of aerial photo interpretation, with particular reference to rock falls.

Most of the landslides were plotted in the northeastern area of the Rokko Mountains, where there are many steep slopes and high landslide susceptibility conditions exist, and at the northern tip of Awaji Island. The observed landslide distribution in Fig. 2 is closely correlated to both the distribution of aftershock epicenters and the trend of mapped active faults. Figure 3 shows the

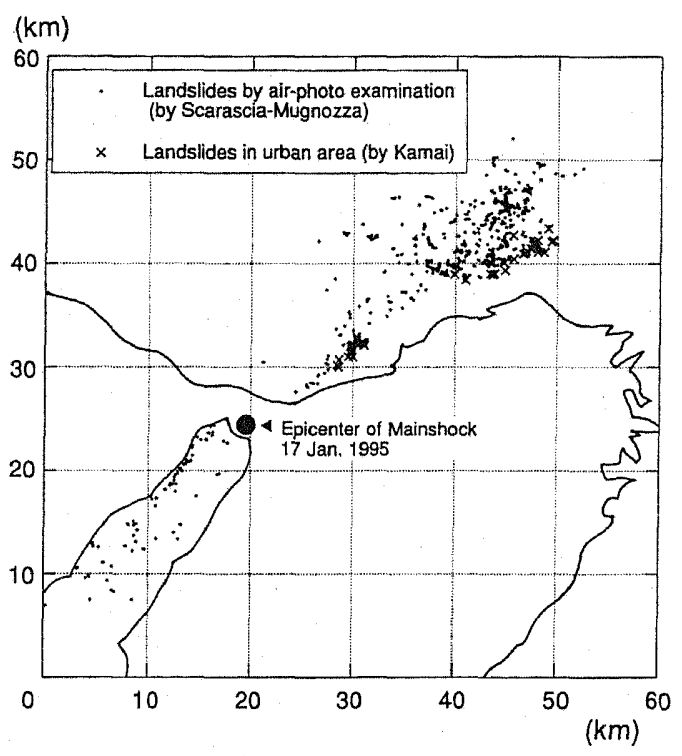

Fig. 2. Distribution of 674 landslides triggered by the 1995 Hyogo-ken Nanbu earthquake. relationship between landslide frequency and the distance from the epicenter of the mainshock. This histogram shows a peak frequency in the distance range of 25 to $30 \mathrm{~km}$. No positive relation between epicentral distance and slope movement occurrence exists. This is mainly because landslides were scattered in and around Nishinomiya City.

In order to examine the relationship between fault rupture zone and landslide distribution, an assumed fault rupture zone and its axis is defined as shown in Fig. 4. The axis is parallel to the Nojima and Suma faults. The assumed rupture zone covers the Nojima, Suma, Suwayama, an Gosukebashi faults. Figure 5 shows the relationship between landslide frequency and the distance from the axis of the assumed fault rupture zone. In contrast to Fig. 3, Fig. 5 shows an exponential-like attenuation trend which shows a significant decrease within $3 \mathrm{~km}$, while the maximum recorded distance is about $10 \mathrm{~km}$. This implies a high concentration of landslides in the assumed rupture zone. Irikura (1995) assumed a fault zone, and reported that the plotted maximum mainshock acceleration versus distance from the fault zone shows clear exponential-like attenuation. If shaking-related sliding mechanisms are most

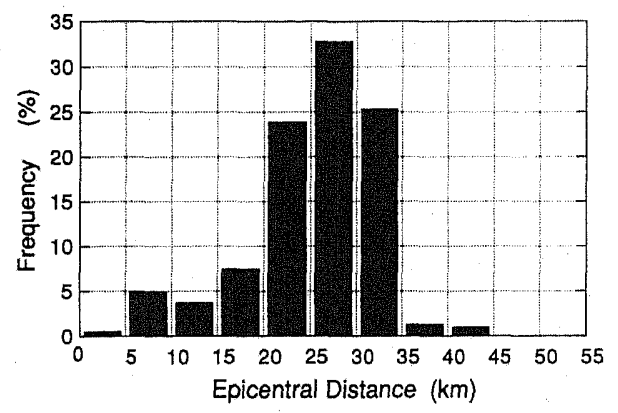

Fig. 3. Landslide frequency versus epicentral distance.

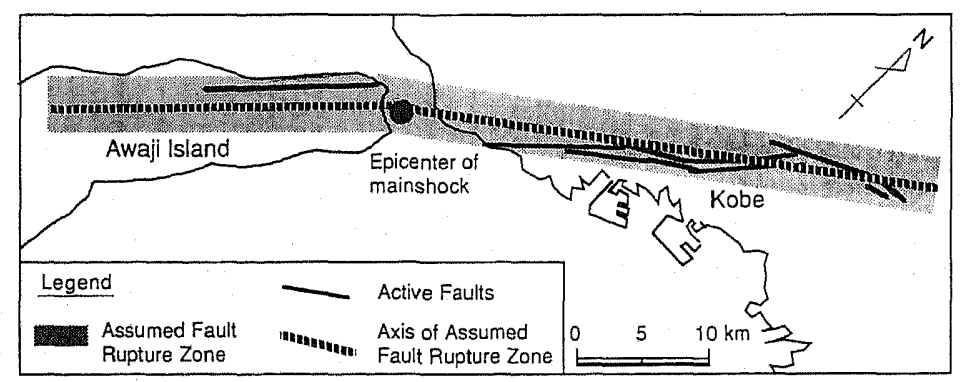

Fig. 4. Location of the assumed rupture zone and its axis of the 1995 Hyogo-ken Nanbu earthquake. 
effective for triggering landslides, it's easily understood that the highest acceleration in the assumed fault zone contributed to the high concentration of landslides around this zone.

Figure 6 shows the relationship between earthquake magnitude and landslide-affected area after Keefer (1984). The landslide affected area by the 1995 Hyogo-ken Nanbu earthquake is about 700 $\mathrm{km}^{2}$ (Fig. 2). This shows that the landslide-affected area in the 1995 Hyogo-ken Nanbu earthquake is

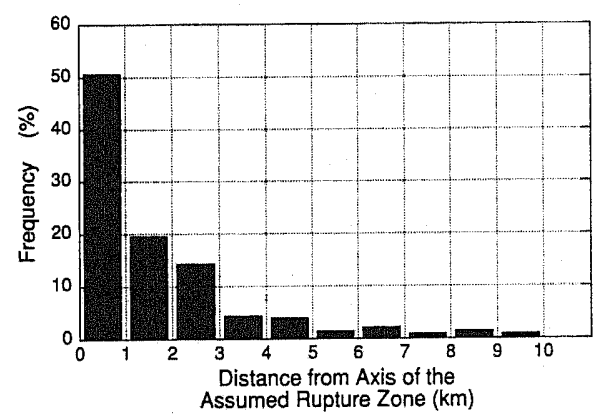

Fig. 5. Landslide frequency versus distance from the axis of the assumed fault rupture zone shown in Fig. 4. smaller than other major earthquake-induced landslide distributions. Not only the landslideaffected area but also the observed maximum distances from the epicenter and the assumed fault rupture zone (respectively 50 and $10 \mathrm{~km}$ ) show lower values when compared with the average based on historical worldwide earthquakes of this magnitude (Keefer, 1984). The 1994 Northridge earthquake, USA, more than ten thousand landslides were counted (Harp and Jibson, 1995). Compared with this number, the number of landslides from the 1995 Hyogo-ken Nanbu earthquake (674) is exceptionally small.

This smaller area and number of landslides are partly due to the exceptionally dry period which preceded the mainshock (Fig. 7). This figure shows that June and July represent the most rainy period in Japan, and intense rainstorms generally occur at the end of this time, as well as in September. This must have lowered the underground water table and greatly limited landslide triggering. Another reason is the large offshore area as seen in Fig. 2. Probably submarine landslides were caused, but they could not be detected.

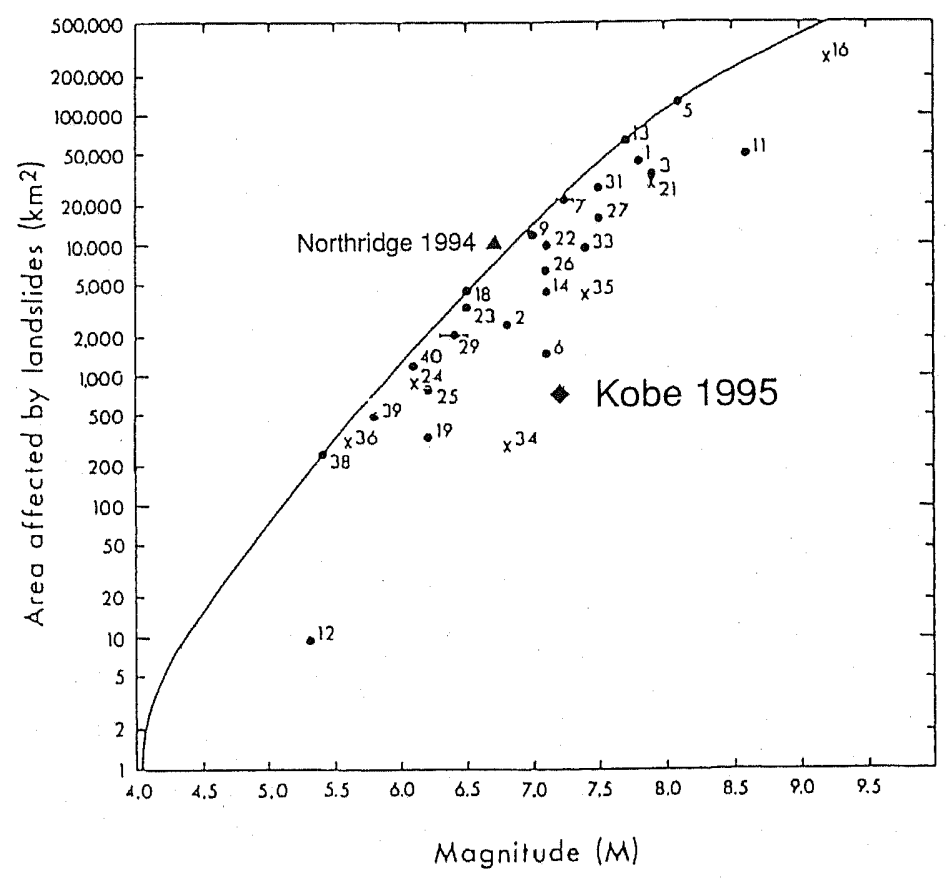

Fig. 6. Statistics of landslide-affected areas triggered by historic earthquakes in the world versus earthquake magnitude (after Keefer, 1984).

Vol. 45, No. 2, 1997 


\section{Long Runout Mechanism of the Takarazuka Golf Course Landslide}

The Takarazuka golf course landslide (Fig. 1(e)) had an exceptionally small apparent friction angle compared with its volume, which was estimated as $2-3 \times 10^{4} \mathrm{~m}^{3}$ (Fukuoka et al., 1995). Figure 8 shows the longitudinal cross section. This shows that the apparent friction angle mobilized during motion was $10.7 \mathrm{deg}$. The initial landslide took place on a comparatively steeper slope, fell down onto a lower gentle slope and traveled more than $130 \mathrm{~m}$. Figure 1(e) shows that this landslide ran along the long golf course and that the runout path was not straight. The most probable reason for this behavior is that undrained loading took place by the sliding mass onto the saturated ground and excess pore pressure was generated under the ground water table, and then the sliding surface was formed there (Fig. 9(a)). This mechanism coincides with the evidence of: 1) landslide mass scraped $2-3 \mathrm{~m}$ of the ground, 2) the landslide path was along a reclaimed valley filled with soft sandy soils, and 3 ) the observed underground water table was $2-3 \mathrm{~m}$ beneath the ground surface.

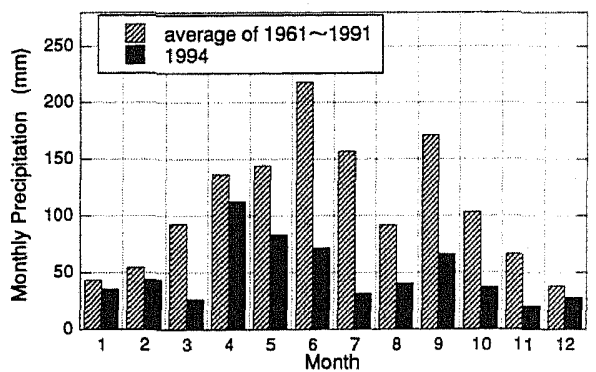

Fig. 7. Comparison of monthly precipitation during the period 1961-1991 and in 1994.
In order to examine the mechanism of the Takarazuka golf course landslide, soil samples were taken from beneath the sliding surface of the frontal edge of the landslide mass and an undrained loading ring shear test was carried out on the saturated sample. Figure 9(b) shows the schematic stress path of the test procedure.

The outline of the test procedure was as follows. 1) Put a slurry-state sample into the sample box of the ring shear apparatus. 2) Consolidate the sample by $0.5 \mathrm{kgf} / \mathrm{cm}^{2}$ of normal stress, which corresponds to the normal stress at about $3 \mathrm{~m}$ beneath the ground, in order to reproduce the initial state of soils before shearing. 3) Start shearing at a constant speed of $0.01 \mathrm{~cm} / \mathrm{s}$ in drained condition. Small excess pore pressure was generated and shearing was kept until dissipated (A in Fig. 9(b)). This procedure was purposed to make the sample residual state and exclude the pore pressure by initial shearing. Shear displacement during this procedure is small compared with that of the successional undrained loading procedure. This enables the separation of excess pore pressure by undrained loading under shearing. 4) Close the drainage valve to change the sample box into undrained condition, and increase normal stress slowly by $2.45 \mathrm{kgf} / \mathrm{cm}^{2}$, which corresponds to loading by sliding mass of about $13 \mathrm{~m}$ in thickness. 5) During normal stress loading, the effective stress path should go up along the failure line (A $\rightarrow B^{\prime}$ in Fig. 9(b)), while the total stress path goes to the right due to the generation of excess pore pressure (A $\rightarrow B$ in Fig. 9(b)). The amount of excess pore pressure depends on the degree of saturation and the dilatancy of the soils during shearing. The apparent friction angle $\left(\phi_{\mathrm{a}}\right)$ mobilized during undrained loading is defined as the angle of the line drawn from the origin to point (B) in Fig. 9(b). 6) Open the drainage valve and switch the sample box

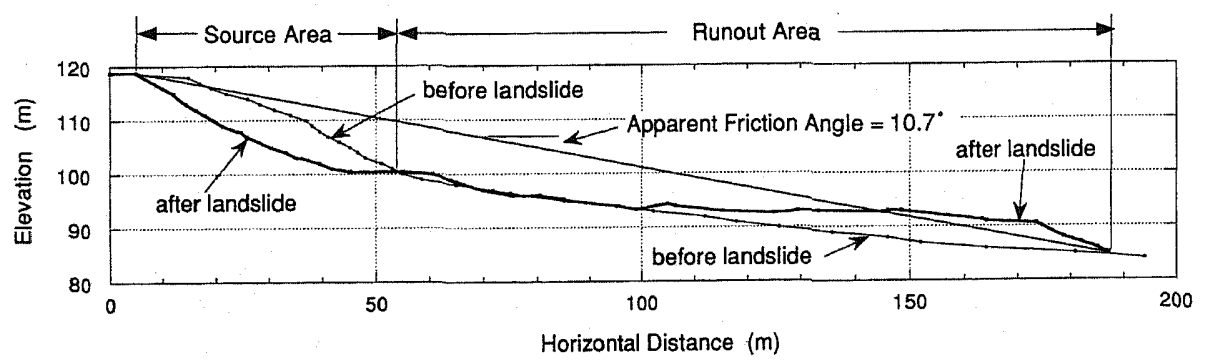

Fig. 8. Longitudinal cross section of the Takarazuka golf course landslide (before and after landslide) and its apparent friction angle. 
a)
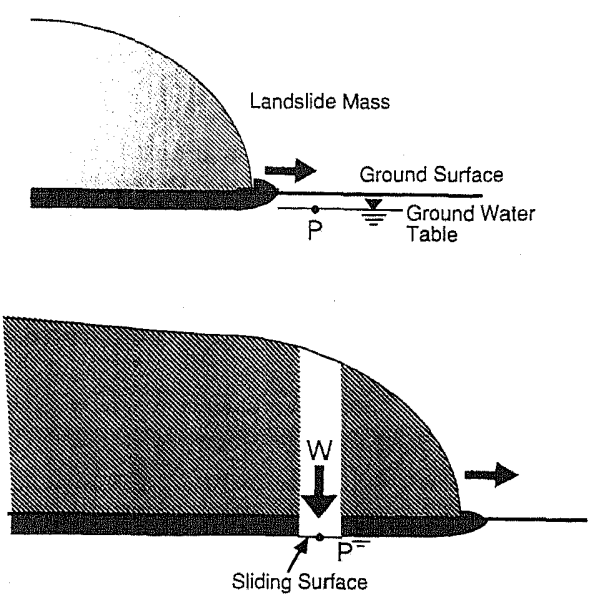

b)

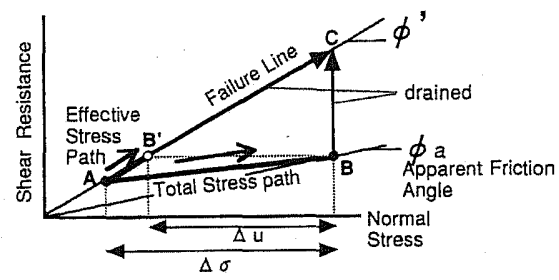

Fig. 9. Schematic figure of (a) undrained loading condition by the moving landslide mass onto saturated ground and (b) stress path of the undrained loading ring shear test and apparent friction angle.

into the drained condition. When the excess pore pressure is dissipated, the effective and total stress paths meets on the failure line. 7) As the final step, normal stress is slowly unloaded in the drained condition to obtain the failure line.

The test results are shown in Fig. 10. Figure 10(a) shows the time series data of normal stress, shear resistance, and pore pressure corresponding to procedures 4) to 7). Figure 10(b) shows the effective and total stress path. The apparent friction angle mobilized after undrained loading is obtained from the slope of line O-B, which was $8.9 \mathrm{deg}$. This value is about $2 \mathrm{deg}$ smaller than the apparent friction angle of the Takarazuka golf course landslide $(10.7 \mathrm{deg})$. The reason for this difference is not certain. However, $8.9 \mathrm{deg}$ is good enough to explain the high mobility of this landslide.
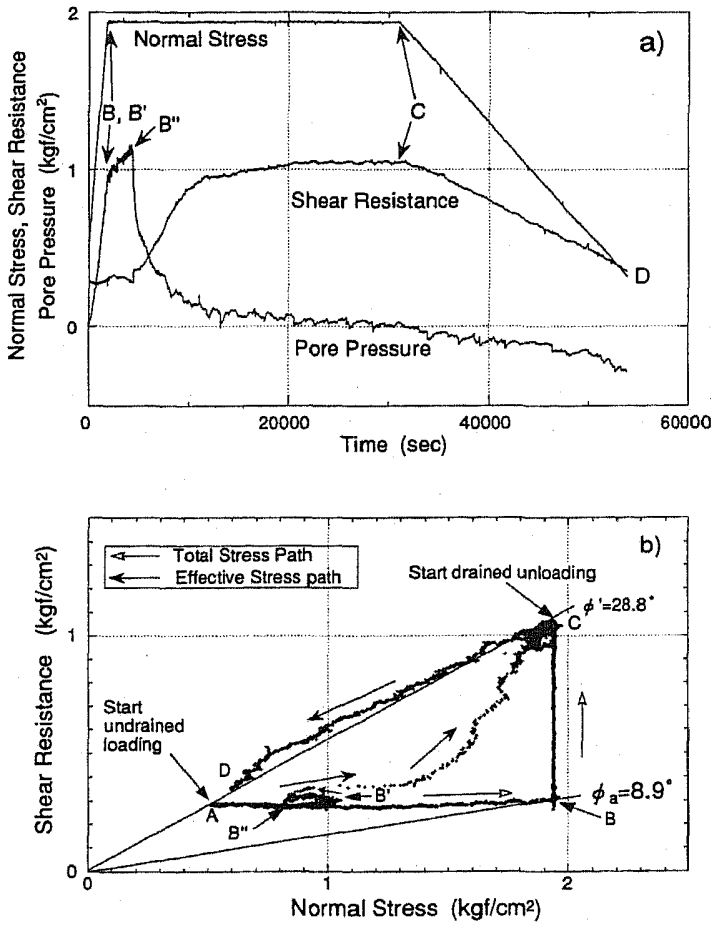

Fig, 10. Results of the undrained loading ring shear test on the saturated sample from the Takarazuka golf course landslide; (a) Time series of the test result and (b) stress path and apparent friction angle.

\section{Conclusion}

The investigations on landslide distribution show low scatter and good correlation with the distribution of aftershocks as well as mapped active faults. Based on the relationship between landslide frequency and distance from the axis of the assumed fault rupture zone, an exponential-like attenuation trend was observed which shows a significant decrease within $3 \mathrm{~km}$, while the maximum recorded distance was as long as $10 \mathrm{~km}$. This attenuation is consistent with the maximum acceleration record of the mainshock in reference to the assumed fault zone by Irikura (1995). This implies that the magnitude of earthquake shaking is the most dominant factor in landslide triggering.

The mechanism of the long runout landslide at the Takarazuka golf course was explained by a low apparent friction angle during undrained loading onto saturated ground. An undrained loading ring 
shear test on saturated samples taken from beneath the sliding surface supported this idea by reproducing a low apparent friction angle of $8.9 \mathrm{deg}$. The value explains the high mobility of this landslide and also the observation that the landslide mass scraped the ground layer at the depth of the underground water table.

\section{REFERENCES}

Fujita, K., T. Kasama, M. Hirano, T. Shinoda, and M. Tanaka-Yamashita, Geology and geomorphology of the Rokko area, Kinki district (Japan), with special reference to Quaternary tectonics, J.Geosci., Osaka City Univ., 4, 71-124, 1971.

Fukuoka, H., K. Sassa, G. Scarascia-Mugnozza, and S.G. Evans, On the runout mechanism of Takarazuka golf course landslide, in Report of the Researches on Landslides and Slope Failures Triggered by the 1995 Hyogoken Nanbu Earthquake and Others, ed. K. Sassa, pp. 49-59, The Japan Landslide Society, 1995 (in Japanese).

Harp, E.L. and R.W. Jibson, Inventory of landslides triggered by the 1994 Northridge, California Earthquake, USGS Open-File Report 95-213, 1-17, 1995.

Irikura, K., Characteristics of strong ground motion by the 1995 Hyogo-ken Nanbu Earthquake, in Invest $i$ - gations and Research on 1995 Hyogo-ken Nanbu Earthquake and Its Damages (Reports for Grant-in-Aid for Scientific Research No.06306022), pp. 103-119, 1995 (in Japanese).

Kamai, T., K. Suzuki, K. Isobe, K. Yamada, M. Jinbo, and T. Sato, Slope deformations in the urban area triggered by the Hyogoken Nanbu Earthquake, in Report of the Researches on Landslides and Slope Failures Triggered by the 1995 Hyogoken Nanbu Earthquake and Others, ed. K. Sassa, pp. 33-47, with supplemental 3 pages of color maps, The Japan Landslide Society, 1995 (in Japanese).

Keefer, D. K., Landslides caused by earthquakes, Geol. Soc. Am. Bull., 95, 406-421, 1984.

Research Center for Earthquake Prediction, Disaster Prevention Research Institute (R.C.E.P./DPRI), Kyoto University, A preliminary report of investigations on Hyogo Prefecture earthquake. Preliminary Report on the Great Hanshin Earthquake of January 17, 1995, D.P.R.I. News Lett., Spec. Issue, 1-8, 1995.

Research Group for Active Faults of Japan, Active Faults in Japan, revised ed., Univ. of Tokyo Press, Tokyo, pp. 272-279, 1995.

Sassa, K., H. Fukuoka, G. Scarascia-Mugnozza, and S. G. Evans, Earthquake-induced-landslides : distribution, motion and mechanisms, Soils Found., Spec. Issue 1995.1.17 Hyogoken-Nambu Earthq., 53-64, 1996. 